\title{
Remarks on Pollen Representation of Mistletoe (Viscum album L.)
}

\author{
Agnieszka M. Noryśkiewicz', Bożena Noryśkiewicz ${ }^{2}$ \\ ${ }^{1}$ Faculty of History, Institute of Archaeology, Nicolaus Copernicus University, Szosa Bydgoska 44/48, \\ 87-100 Toruń, Poland; \\ e-mail: agnieszka.noryskiewicz@umk.pl \\ ${ }^{2}$ Faculty of Earth Sciences, Nicolaus Copernicus University, ul. Lwowska 1, 87-100 Toruń, Poland; \\ e-mail: norys@umk.pl,
}

Received: 20 April 2017/Accepted: 12 June 2017

\begin{abstract}
Productivity and dispersal of mistletoe pollen (Viscum album L.) is discussed on the basis of its representation in fossil sediments ( 2 profiles representing the Holocene successions - one from Lake Strażym and one from Retno peatbog), moss samples (15 samples covering a period of 6 years), annual pollen monitoring data (19 years) and pollen amount in the flower and inflorescence investigation. The main question to be clarified is whether and how closely the moss samples reflect the presence of mistletoe. The results of the study have proved that even a single pollen grain may indicate the presence of a large Viscum population near the site.
\end{abstract}

Keywords: Viscum album, pollen analysis, surface samples, modern annual pollen deposition, fossil pollen diagrams.

\section{Introduction}

The studies on the spread of Viscum pollen were performed in the Brodnica Lake District (Northern Poland), where annual monitoring by Tauber-traps has been conducted since 1998. A large number of mistletoe shrubs, semi-parasites on the Tilia cordata Mill. growing at a distance of 40 meters from the Tauber trap, inspired the research on the spread of Viscum pollen. In winter and early spring, when trees stand leafless, the twigs of Viscum, can be seen from afar (Fig. 1).
European mistletoe is a dioecious, evergreen species, which blooms from February until April and lives at the expense of its hosts. Various tree species can serve as hosts (Madeja et al. 2009). Male flowers are larger than female and, like twigs, they are characterized by a yellow-green colour (Fig. 2). Female flowers show entomophilous features and are visited and pollinated by insects, among which bees probably play an important role. However, the possibility that mistletoe is also a wind-pollinated species was confirmed as well (Hatton 1965). 


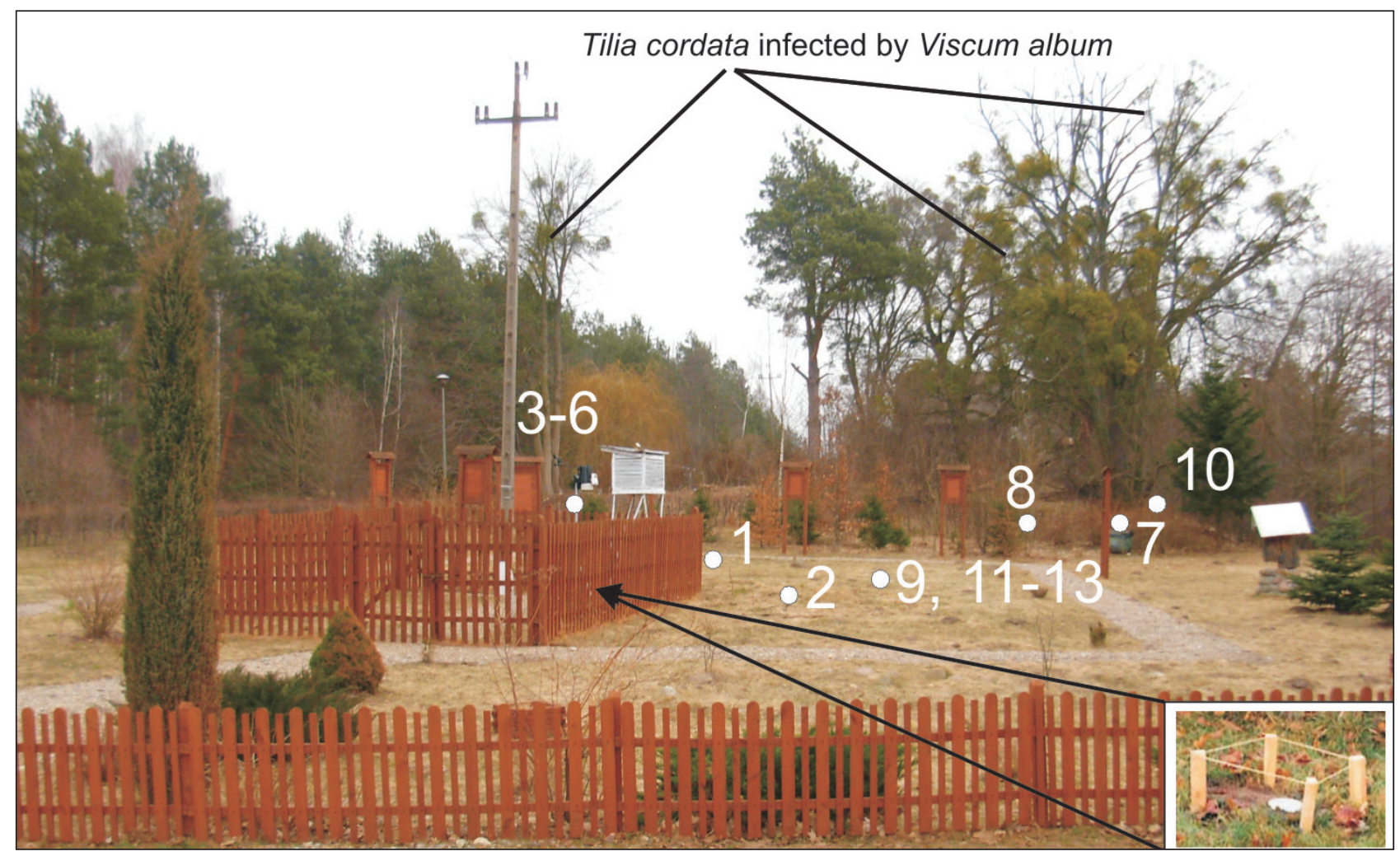

Figure 1. Locations of the Tauber-style pollen trap and moss samples in Grzmięca

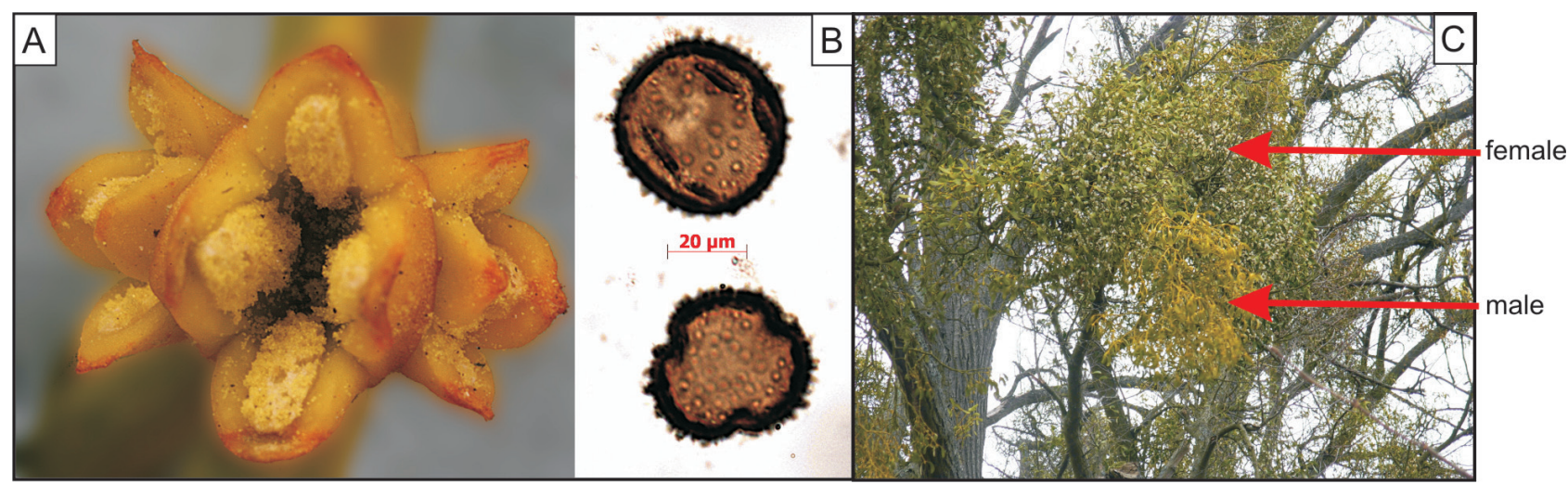

Figure 2. Mistletoe (Viscum album L.); A - inflorescences, photo by T. Górzyński; B - pollen; C - shrubs, photos by A.M. Noryśkiewicz

Iversen, in his classic paper of 1944 (Iversen 1944) used mistletoe pollen as a climate indicator. He suggested that the absence or the presence of the pollen in the pollen diagram provided data on the climate. Viscum is a continental element requiring warm summers, although it can thrive at lower summer temperatures if winters are mild. According to Jacomet and Kreuz (1999; after Madeja et al. 2009) the presence of mistletoe pollen grains indicates mean temperature of the warmest month of over $15^{\circ} \mathrm{C}$ (Iversen $1944-12-13^{\circ} \mathrm{C}$ ) and very warm summer seasons. This taxon is also indicative of mean temperature of January higher than $-7^{\circ} \mathrm{C}$ (Iversen 1944 - higher than $-8^{\circ} \mathrm{C}$ ).

The aim of the study has been to compare the share of mistletoe in the tree stand and the presence of its pollen 
in the pollen rain. To investigate the possible relationship between air temperature and participation of mistletoe in the pollen rain, our results were compared with the average monthly temperatures.

\section{Material and methods}

The discussion of pollen productivity and dispersal of Viscum album L. is based on the moss samples study (involving 15 samples collected during 6 years), annual pollen rain (during 19 seasons; 1998-2016) and fossil material (two profiles representing the Holocene successions, from Lake Strażym and the peatbog of Retno). The examination of annual pollen rain has been conducted in accordance with the Pollen Monitoring Programme recommendations (Hicks et. al 1996; www.pollentrapping.org). One of the Tauber pollen traps is located in Grzmięca near the head office of the Brodnica Landscape Park. The profile of sediments representing Holocene vegetation history from Lake Strażym (Noryśkiewicz 1987) was taken about 300 metres south of the Tauber trap. The peat monolith of Retno was collected from the central part of its small depression (kettle hole) about two kilometres north-west of Grzmięca (Fig. 3) (Noryśkiewicz 2012).

A series of moss samples in Grzmięca site (13 samples) was collected around the Tauber trap. In this area, mistletoe occurred on Tilia cordata, Populus nigra and Crataegus sp. Six of the moss samples were collected under the canopy of the host tree $(3,4,5,7,8$ and $10-$ Fig. 1). One was taken not far from the tree infected by mistletoe (6 - Fig. 1) and the remaining samples were taken from an open area, near the Tauber trap. The last two moss samples were taken from the Retno area. One from the peatbog, near the place from which fossil profile was taken. The second was collected under the mistletoe that occurs closest to the profile location (Fig. 3).

Moreover, to calculate pollen productivity of mistletoe, male mistletoe flowers were collected in March 2011
(Tab. 1). Pollen production was calculated on the basis of 40 flowers and 30 inflorescences, randomly selected during the early spring of 2011. In each of the seven cases (macerations), 10 specimens were prepared (10 flowers in samples 1, 3, 5 and 7 and 10 inflorescences in samples 2,6 and 8 it was). In order to compare mistletoe pollen production rates, flowers and inflorescences of Juniperus communis, Pinus sylvestris and Cornus sanguinea were also analyzed (Tab. 2). The calculation of pollen amount in each sample was based on the addition of ten tablets of Lycopodium (Strockmarr 1971). The batch number of Lycopodium tablets was 177745.

\section{Results}

\subsection{Present-day samples}

In individual flowers, a large variation in Viscum pollen production was observed. Pollen amount in the oldest individual flowers ranged between 17,535 and 57,448, and between 20,451 and 27,337 in inflorescences - Tab. 1).

The average amount of pollen produced by a single Viscum flower, calculated from 130 single flowers (both individual and from the inflorescence) is 31,335 , while the inflorescence produces an average of 72,691 pollen grains (Tab. 1).

Studies on mistletoe distribution in the Mazurian Lakeland (Northern Poland) have shown that almost 50\% of specimens prefer southern exposure and the largest part of the fruit (more then 50\%) occurs within southern exposure as well (Stypiński 1997).

Similarly, we may formulate a hypothesis that pollen production by mistletoe flowers may result from their exposure to light. It confirms Troels-Smith's (1960) suggestions that the flowering of mistletoe depends on its ability to assimilate.

The pollen spectra from the mistletoe flowers also contained single taxa other than Viscum. We found a few ex-

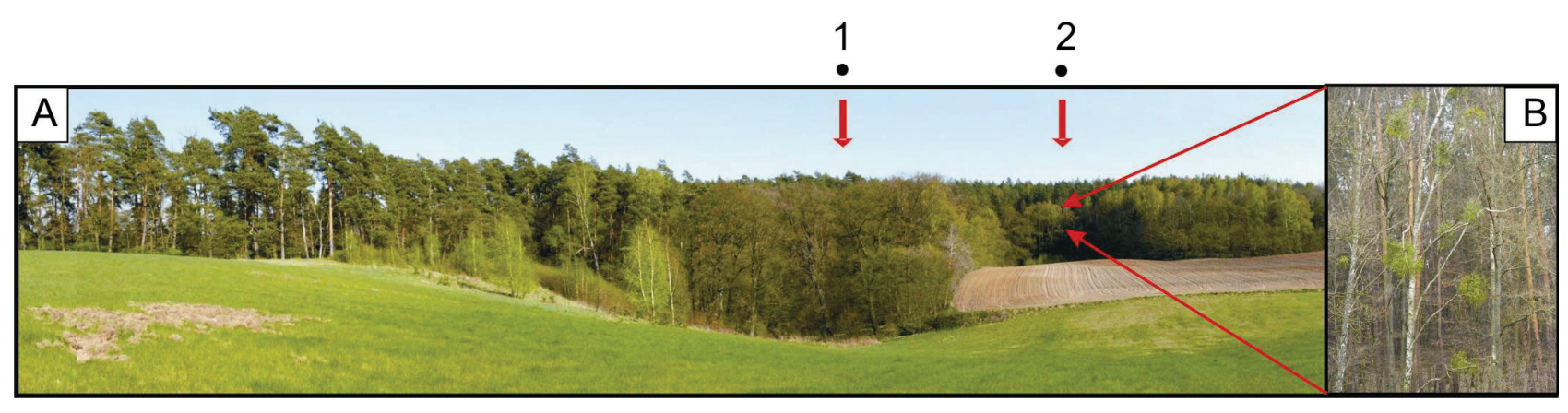

Figure 3. Retno; A - View of the peat bog. 1 - location of palynological profile and surface Sample 1; 2 - location of Viscum shrub and surface Sample 2; B - Zooming the tree with mistletoe over Sample 2, photo A by T.M. Karasiewicz 
Table 1. Amount of Viscum pollen in the single flowers and in the inflorescence

\begin{tabular}{|c|c|c|c|c|c|}
\hline $\begin{array}{c}\text { Number } \\
\text { of sample }\end{array}$ & $\begin{array}{c}\text { Quantity } \\
\text { of pollen counted } \\
\text { in ten single flowers }\end{array}$ & $\begin{array}{c}\text { Quantity of pollen } \\
\text { counted in ten } \\
\text { inflorescences } \\
\text { (samples 2,6,8) }\end{array}$ & $\begin{array}{c}\text { Quantity } \\
\text { of Lycopodium spores } \\
\text { counted (added } \\
\mathbf{1 0 x 1 8 5 8 4 0} \text { spores) }\end{array}$ & $\begin{array}{c}\text { Quantity } \\
\text { of pollen in the } \\
\text { inflorescence }\end{array}$ & $\begin{array}{c}\text { Quantity } \\
\text { of pollen } \\
\text { in one male } \\
\text { flower }\end{array}$ \\
\hline 1 & 2,235 & & 723 & & 57,448 \\
\hline 3 & 2,080 & & 2,143 & & 44,430 \\
\hline 5 & 2,022 & & 1,373 & & 27,535 \\
\hline 7 & 2,013 & 2,083 & 472 & 82,013 & 27,337 \\
\hline 2 & & 2,070 & 627 & 61,354 & 20,451 \\
\hline 6 & & 2,010 & 500 & 74,708 & 24,902 \\
\hline 8 & & & & 72,692 & 24,230 \\
\hline Average 2, & & & & & \\
\hline 6,8
\end{tabular}

Table 2. Amount of pollen in the different flowers (collected and counted in 2011)

\begin{tabular}{|c|c|c|c|}
\hline $\begin{array}{c}\text { Number } \\
\text { of sample }\end{array}$ & Taxa & Quantity of pollen in the inflorescence & Quantity of pollen in one flower \\
\hline 1 & Pinus sylvestris & $1095,780(40$ single flower $)$ & $27,394(68$ single flowers $)$ \\
\hline 2 & Juniperus communis & & $331,222(10$ single $)$ \\
\hline 3 & Cornus sanguinea & & $9,327(10$ single $)$ \\
\hline 4 & Viscum album & $72,692(9$ flowers: 3 inflorescences & $31,335(130$ single $)$ \\
\hline
\end{tabular}

traneous pollen grains in the samples, which resulted from visits by insects during the flowering. They contained not only Viscum pollen but 7 grains of Alnus and two grains of Corylus avellana as well. All of the Viscum flowers were collected between $24^{\text {th }}$ and $26^{\text {th }}$ of March 2011. This is consistent with the flowering season of the plants, i.e. Alnus, which generally flowers in March and April and Corylus avellana - in February and March.

Moss samples for pollen analysis were collected in early autumn and early spring (Fig. 4.). The transect between the linden trees with mistletoe (Samples 3-6 and 7, 8, 10) and the Tauber trap runs through the anthropogenic community (Artemisia-Conyza and Poa pratensis-Festuca rubra). In each of the samples more than 1,000 grains were counted (1,170 and 1,819). Pollen percentages of Viscum in surface samples are very low and in samples from the middle part of the open area (Samples 1, 2, 9, 12 and 13 Fig. 1, 4) there is no Viscum pollen at all.

Eleven grains of Viscum were counted in Sample 7, which was taken exactly under the mistletoe shrub. In the other samples, the following numbers of Viscum pollen grains were encountered: one (Samples 5 and 11), two (4), three (3 and 6), six (8) and nine (10).

In five samples collected from the site directly under the Tilia trees with mistletoe, where pollen could have dropped or could have been washed down into the litter and moss, the amount of Viscum was $0.9 ; 0.6 ; 0.5 ; 0.3$ and $0.2 \%$ (in the AP+NAP total). In Sample 5, the first Viscum pollen was found after the count of 696 arboreal and non-arboreal (AP and NAP) pollen. We suppose the value is approximately the necessary minimum for the Viscum pollen to occur in the pollen sample. 


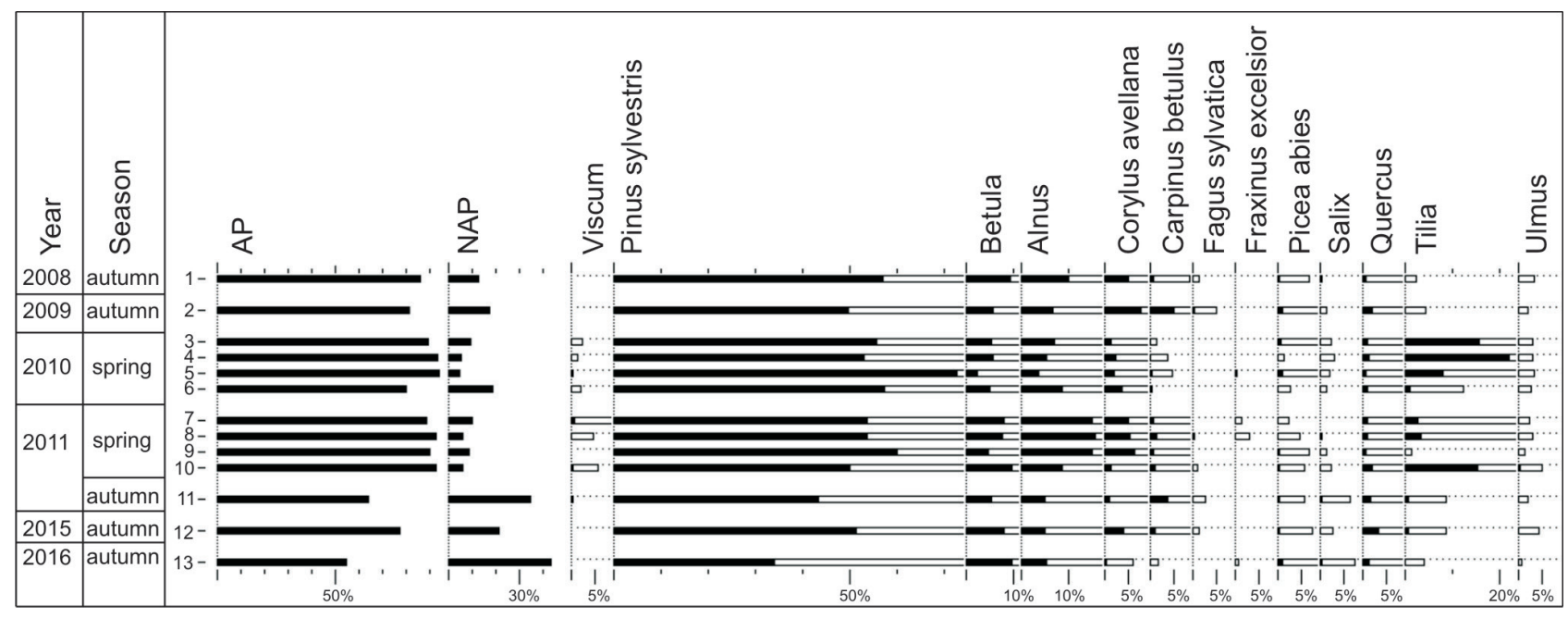

Figure 4. Grzmięca site; Pollen percentage of the selected taxa in moss sample diagram. Location of the samples (1-13) as in Fig. 1

Two more moss samples were collected at the Retno site (Figs. 3 and 5). Today, there are no mistletoe shrubs on the trees growing on the peatland or on the slopes. The community with Quercus and Corylus avellana overgrows the central part of the Retno peatland. The slopes are overgrown with typical hornbeam forest (Tilio-Carpinetum typicum).

One moss sample from Retno (Sample 1) was taken from the peatbog, near the place from which fossil profile was taken, the other (Sample 2) under the mistletoe that grows closest to the profile location (Fig. 3). Pollen percentages of Viscum are very low too (Fig. 5) but its pollen was also present in the moss Sample 1 from the area where no mistletoe shrubs grow on the trees. Pollen percentage in the annual pollen deposition from Grzmięca is also very low and does not exceed $0.3 \%$ (Fig. 4). This indicates that the ample presence of mistletoe on the trees surrounding the Tauber trap clearing is poorly manifested in the pollen rain (Fig. 6).

The results of the study have led us to believe that Viscum single flower is a good producer of pollen, especially when the results from the different plants are compared (Tab. 2). The problem with poor representation of mistletoe by pollen in our present-day moss sediment can be attributed to the small quantities of Viscum male flowers.

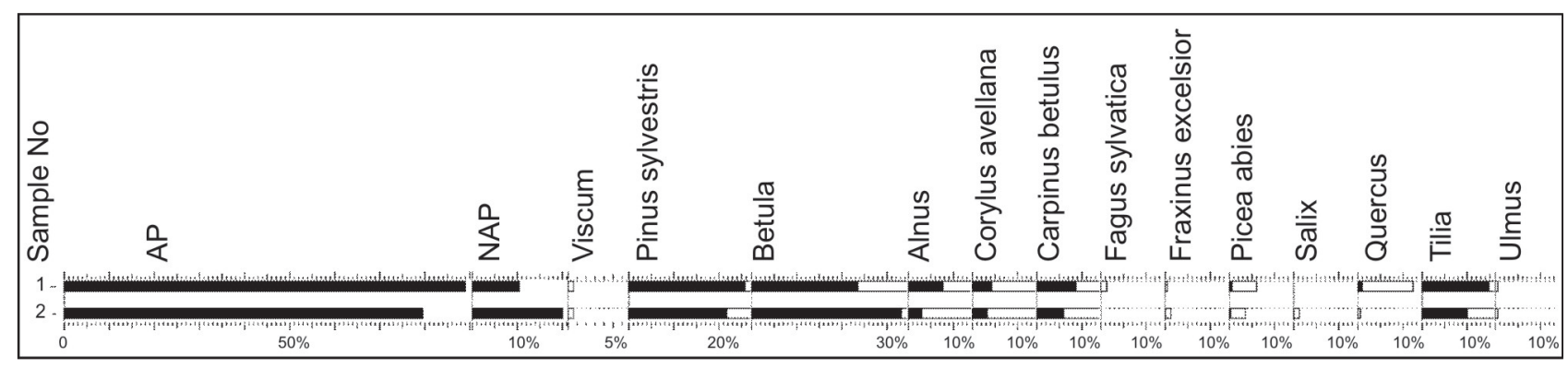

Figure 5. Retno site; Pollen percentage of the selected taxa in moss sample diagram. Location of the samples (1-13) as in Fig. 3 


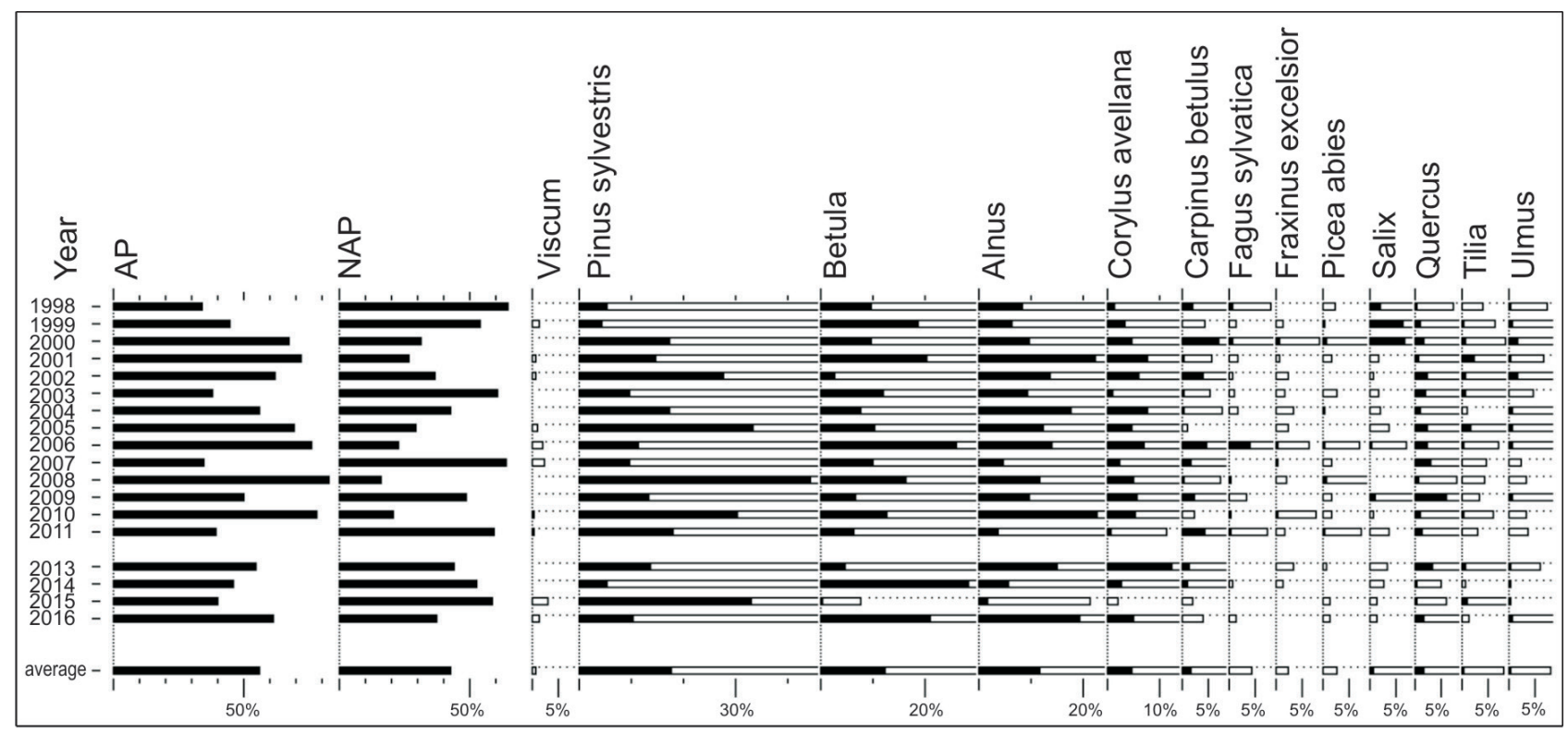

Figre 6. Annual pollen deposition (Tauber trap from Grzmięca); Pollen percentage diagram of the selected taxa

\subsection{Fossils sediment}

Time/age scale in the profiles from Retno and Strażym is only an estimation. The sediment was not annually laminated, so we have not been able to obtain results that are more accurate. Similar low percentage values of Viscum and its discontinuous occurrence have been found in the Strażym and the Retno profiles. The first pollen grains of Viscum were recovered from the Atlantic Period in the Strażym profile (Fig. 7) and from the end of the Boreal Period in the Retno profile (Fig. 8), but they did not exceed $0.15 \%$, and occurred until the younger part of the Subatlantic Period - corresponding to the early medieval times.

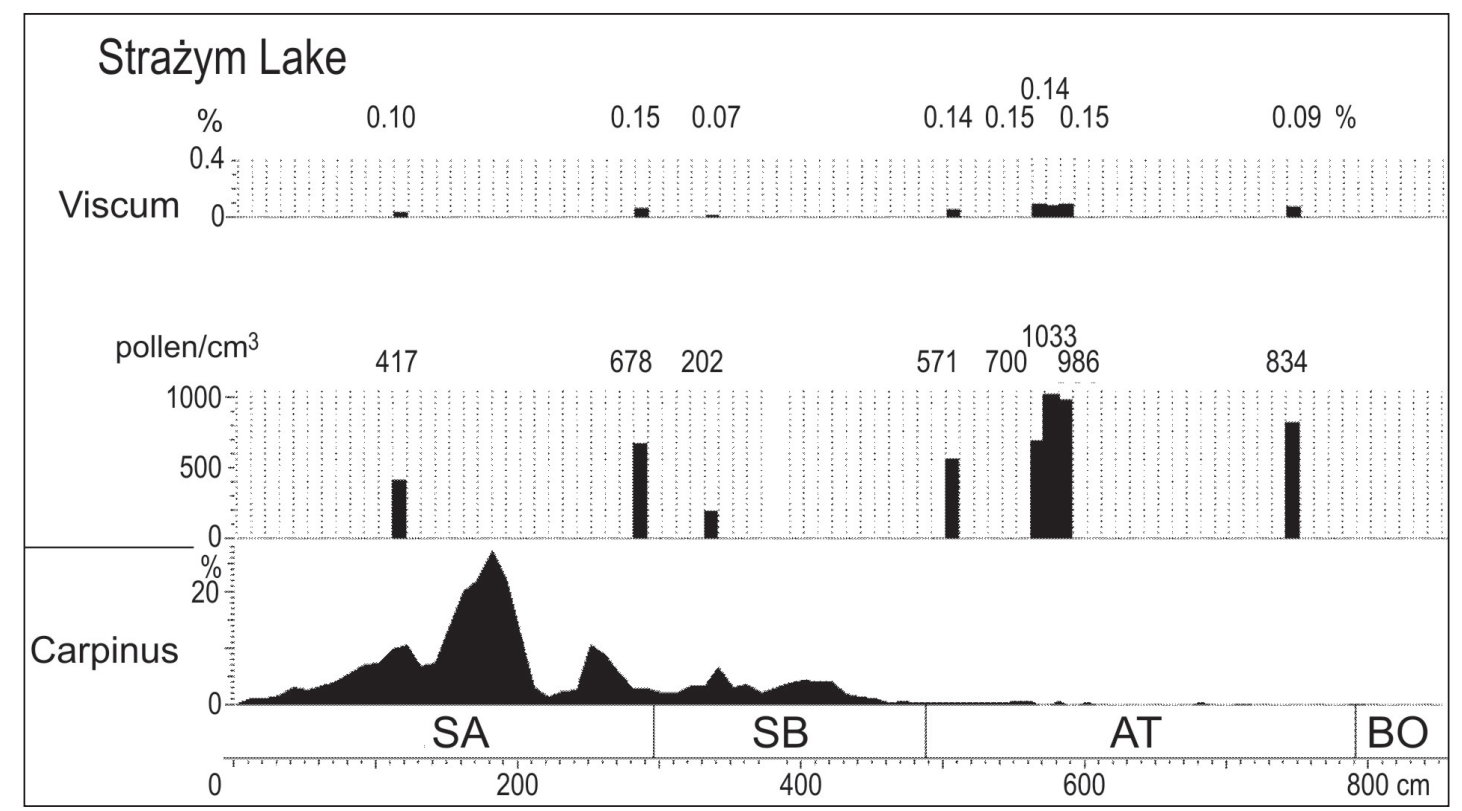

Figure 7. Strażym; Percentage and concentration of Viscum in the Holocene 


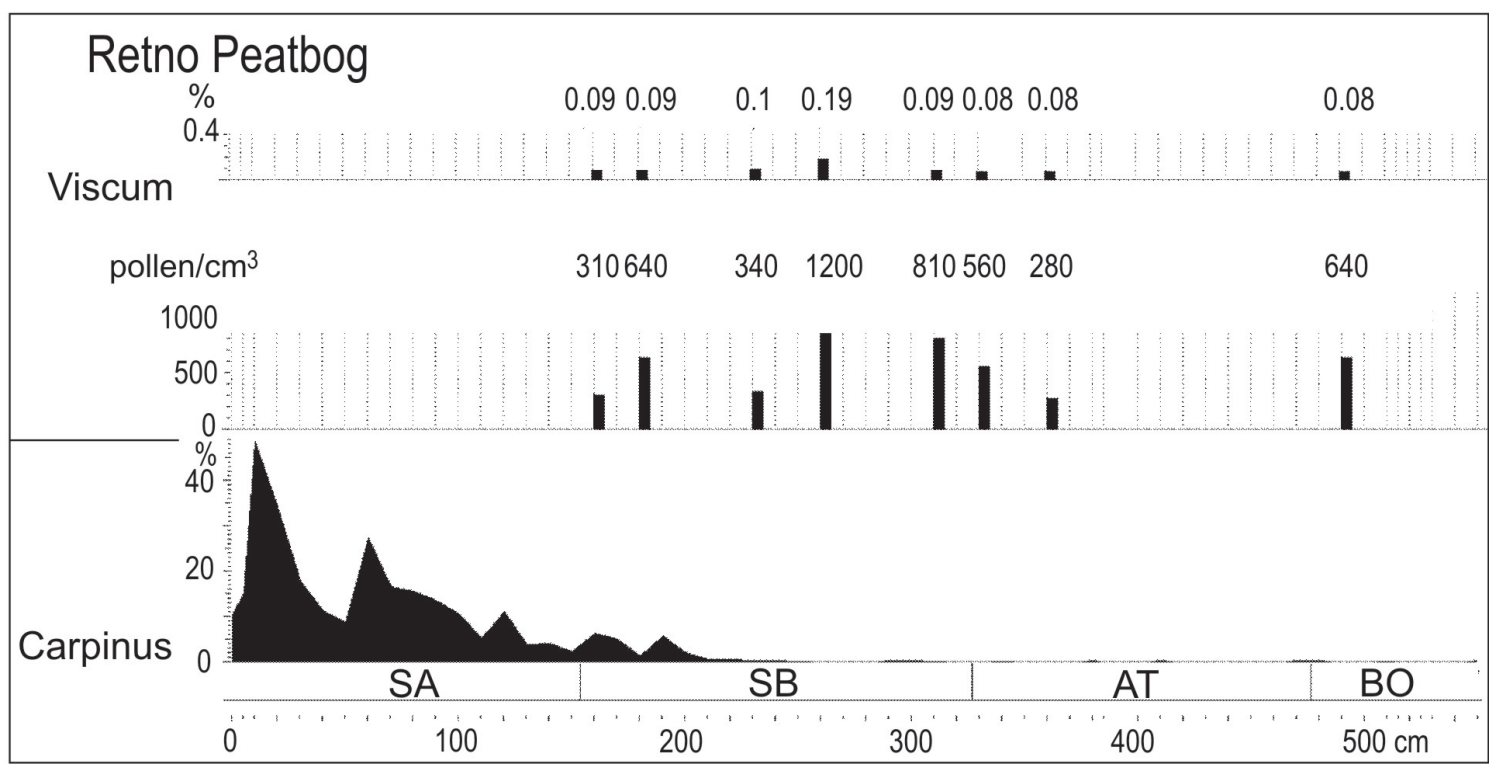

Figure 8. Retno; Percentage and concentration of Viscum in the Holocene

We may observe migration and appearance of mistletoe in Poland on the basis of isopollen maps (Granoszewski et al. 2004). In the period between $8500-7500 \mathrm{C}^{14}$ years BP, isopollen maps record the gradual expansion of mistletoe in Poland and by $3500 \mathrm{C}^{14}$ years $\mathrm{BP}$ its range had covered the whole country, but the highest values do not exceed $0.6 \%$. A significant reduction in mistletoe pollen values occurred between 3000 and $500 \mathrm{C}^{14}$ years BP. On a $100 \mathrm{C}^{14}$ years BP isopollen map of Viscum (Granoszewski et al. 2004), mistletoe presence has been recorded only in the Małopolska Upland. Such a considerable decline in the occurrence of mistletoe may have resulted from the climate cooling of the Little Ice Age.

At present, a significant spread of mistletoe can be observed in Poland. It has been noted that the species adapts well to heavily transformed habitats (Zachwatowicz et al. 2008), so now it may be recognized not only as a climatic indicator (Iversen 1944), but as a synanthropic species as well (Zachwatowicz et al. 2008). The synanthropic nature of the spread of mistletoe is also confirmed by its location in the Brodnica Lake District. Mistletoe absence in forests and its expansion near human settlement and communication routes demonstrates that it is a synanthropic plant in our climate zone.

The presence of Viscum pollen in pollen spectra has been compared with the results of pollen monitoring, moss samples and with the contemporary share of mistletoe shrubs.

The appearance of Viscum pollen in the Holocene is related to improved climate conditions. However, the causes of the subsequent decrease and even disappearance remain unclear. Further research is required to determine which factor: the climate, human activity, fires or insects attacking the trees was responsible. There are numerous publications documenting the impact of these factors on the present-day population of mistletoe. The expansion of new species of trees may have been an important factor, too.

The next stage of the research will be the comparison of the results of annual pollen monitoring with the meteorological data from the Grzmięca weather station. The first observations indicate that the meteorological data from the station in Grzmiecca show a considerable year-to-year variability. The presence of Viscum pollen grains in Grzmięca is not clearly connected with the average monthly temperatures. Low temperatures in January and February (min. $-15.5 ;-18.2^{\circ} \mathrm{C}$, respectively) in 2000,2003 and 2004 are probably responsible for the absence of the Viscum pollen. But how to explain the relatively high percentage of mistletoe in 2006 and low average temperatures in the beginning of the year? These aspects require further research.

\section{Conclusions}

The main problem that we have tried to explain is whether and how closely pollen rain reflects the presence of Viscum shrubs. Now we can assume that even a single pollen may indicate the presence of a large Viscum population. Furthermore, the moss sample from the Retno site proves 
that Viscum pollen is able to spread in deciduous forests despite the growth of leaves on the trees.

Another problem is why so many positions of Viscum shrubs are so poorly represented in pollen spectra. It should be remembered that the low presence of mistletoe pollen may be influenced by several different factors. Therefore, mistletoe should not be considered to be a poor pollen producer, it is a species pollinated by both insects and wind. Our results have shown that Viscum is not a low pollen producer, but confirmed its inefficient pollen dispersal.

Mistletoe is dioecious, but female species predominate. Such a situation can be observed not only in Grzmięca, but in other areas in Poland, too. This is because males, compared with females, are less resistant to frost. Another reason for the variability of the structure may be higher mortality of male plants both at the embryonic as well as the later stages of development.

In conclusion, we may underscore that despite the ample presence of mistletoe in the tree stand, the amount of Viscum pollen in the pollen spectra can be low or none. The determination of the presence of Viscum pollen in the sample requires that a sufficient number of pollen grains are counted in each sample. Our calculations show that about 1000 AP and NAP (and not less than 700) is approximately the minimum requireed to meet the test of Viscum pollen in the sample.

\section{References}

Granoszewski W., Nita M. \& Nalepka D., 2004, Viscum album L. - Mistletoe, [in:] Late Glacial and Holocene history of vegetation in Poland based on isopollen maps, M. Ralska-Jasiewiczowa, et al., (eds.), W. Szafer Institute of Botany, PAS, Kraków: 237-243.

Hatton R.H.S., 1964, Pollination of Mistletoe (Viscum alba L.), Proceedings of the Linnean Society of London 176(1): 67-76.

Hicks S., Ammann B., Latałowa M., Pardoe H. \& Tinsley H., 1996, European Pollen Monitoring Programme,
Project Description and Guidelines. Oulu University Press, Oulu, Finland.

Iversen J., 1944, Viscum, Hedera and Ilex as climate indicators, Geol. Forh. 66(3): 463-483.

Jacomet S., Kreuz A.,1999, Archäobotanik, Verlag Eugen Ulmer. Stuttgart.

Madeja J., Harmata K., Kołaczek P., Karpińska-Kołaczek N., Piątek K. \& Naks P., 2009, Bracken (Pteridium aquilinum (L.) Kuhn), mistletoe (Viscum album (L.)) and bladder-nut (Staphylea pinnata (L.)) - mysterious plants with unusual applications, [in:] Cultural and Ethnobotanical Studies, Plants and Culture: seeds of the cultural heritage of Europe, ed. J-P. Morel, A.M. Mercuri: 207-215.

Noryśkiewicz A.M., 2012, Historia roślinności i klimatu zarejestrowana w małym bezodpływowym zagłębieniu w rezerwacie Retno [The vegetation and climate history recorded in a small, kettle hole at the Retno reserve], [w:] Postglacjalna historia zagłębienia bezodpływowego w rezerwacie Retno (Pojezierze Brodnickie) [Postglacial history of the kettle hole in Retno Reserve (Brodnickie Pojezierze)], M.T. Karasiewicz, P. Hulisz \& M. Świtoniak (eds.), Wydawnictwo Naukowe UMK: 87-107.

Noryśkiewicz B., 1987, History of Vegetation during the Late-Glacial and Holocen in the Brodnica Lake District in Light of Pollen Analysis of Lake Strażym Deposits. Acta Palaeobotanica 27(1): 283-304.

Stypiński P., 1997, Biologia i ekologia jemioły pospolitej (Viscum album, Viscaceae) w Polsce [Biology and Ecology of the European Mistletoe (Viscum album, Viscaceae) in Poland]. Instytut Botaniki im. W. Szafera PAN, Kraków.

Troels-Smith J., 1960, Ivy, Mistletoe and Elm Climate Indicators - Fodder Plants, Denmarks Geologiske Undersøgelse, Seria IV, 4(4): 1-32.

Zachwatowicz M., Petrović K., Sudnik-Wójcicka B., 2008, The occurrence of European mistletoe under the conditions of hihg human impact in the central part of Warsaw, Poland. Problemy Ekologii Krajobrazu 22: $101-114$. 